\title{
The role of alliances in creating legitimacy of sustainable technologies: A study on the field of bio-plastics
}

\author{
Maikel Kishna ${ }^{a}$, Eva Niesten ${ }^{\text {b, }}{ }^{*}$, Simona Negro ${ }^{c}$, Marko P. Hekkert ${ }^{c}$ \\ ${ }^{a}$ Vrije Universiteit Amsterdam, De Boelelaan 1105, 1081 HV, Amsterdam, The Netherlands \\ ${ }^{\mathrm{b}}$ Alliance Manchester Business School, The University of Manchester, Booth Street West, M15 6PB, Manchester, United Kingdom \\ ${ }^{\text {c } C o p e r n i c u s ~ I n s t i t u t e ~ o f ~ S u s t a i n a b l e ~ D e v e l o p m e n t, ~ U t r e c h t ~ U n i v e r s i t y, ~ H e i d e l b e r g l a a n ~ 2, ~} 3584$ CS, Utrecht, The Netherlands
}

\section{A R T I C L E I N F O}

\section{Article history:}

Received 20 January 2016

Received in revised form 14 June 2016

Accepted 15 June 2016

Available online 18 June 2016

\section{Keywords:}

Alliances

Legitimacy

Sustainable technology

Bio-plastics

\begin{abstract}
A B S T R A C T
In the transition to a more sustainable world, the development of sustainable technologies needs to be accompanied by promoting the legitimacy of the technologies. Consumers that perceive a technology as desirable and appropriate are more likely to adopt it. Organizations can collaborate to enhance the legitimacy of new technologies. While previous research has emphasized the importance of collaboration in the field of sustainability, it has not studied collaborative efforts of organizations aimed at achieving legitimacy of sustainable technologies. The contribution of this paper is therefore to analyze the role of inter-organizational alliances in creating legitimacy for a sustainable technology. The paper contributes to the literature by analyzing how alliances create three types of legitimacy: technology-sourced market legitimacy, technology-sourced social legitimacy and technology legitimacy. It focuses on the case of bioplastics, which is emerging as a sustainable technology in the chemical industry. The analysis is based on a database containing information on 105 alliances in the field of bio-plastics over the period 1990-2013. The results show that alliances aim to promote technology-sourced market and social legitimacy by providing access to the sustainable technology of a partner, by collaboratively developing a sustainable technology, or by providing the technology of a partner with access to customers and production capacity. Alliances promote technology legitimacy by relying on positive externalities, by exercising their signaling role, and by acting as institutional entrepreneurs. The paper concludes that there are differences between alliances that create technology-sourced market and social legitimacy on the one hand, and technology legitimacy on the other hand. The first type of alliances are often bilateral alliances between for-profit companies that produce and market sustainable technologies. In contrast, alliances that stimulate technology legitimacy are multilateral alliances that operate in the pre-competitive stage of the value chain and involve not-for-profit organizations.
\end{abstract}

๑) 2016 Elsevier Ltd. All rights reserved.

\section{Introduction}

The plastics industry has been under pressure to develop sustainable technologies since the 1990s (Hoffman, 1999). Plastics are produced mainly from petroleum and represent the largest field of application for crude oil (Siracusa et al., 2008; Shen, 2011). The durability of plastics and the use of oil as feedstock are causing environmental problems related to waste, use of non-renewable resources, and climate change (Ren, 2003; Shen et al., 2009; Chadha, 2011). In response to these concerns, different bio-

\footnotetext{
* Corresponding author.

E-mail addresses: m.j.kishna@vu.nl (M. Kishna), eva.niesten@manchester.ac.uk (E. Niesten), S.O.Negro@uu.nl (S. Negro), M.P.Hekkert@uu.nl (M.P. Hekkert).
}

plastics have emerged as sustainable technologies (Iles and Martin, 2013). Bio-plastics are bio-degradable or are made from bio-based raw materials (Álvarez-Chávez et al., 2012; Iles and Martin, 2013). They can reduce the dependency of plastics production on oil, and can contribute to solving environmental issues.

The diffusion of bio-plastics is heavily dependent on the legitimacy that the new technology is able to acquire and the legitimacy of the organizations that develop, sell and promote the technology (e.g. Hekkert et al., 2007; Markard et al., 2016). Legitimacy refers to a generalized perception that a technology or organization is desirable, appropriate and socially accepted (Seo and Creed, 2002; Thornton and Ocasio, 2008; Rao et al., 2008). Since the creation of legitimacy involves a variety of actors and is a collective, social and transactional process, it has been argued that it is especially 
important to examine legitimacy within an alliance context (Pfeffer and Salancik, 2003; Dacin et al., 2007). However, empirical research on both the legitimating roles of alliances and the legitimacy of technologies is very limited (Markard et al., 2016; Dacin et al., 2007; Rao et al., 2008). Binz et al. (2016: 250) have argued that legitimacy is studied at the macro-level, but "how legitimacy is actively built up through the interplay of different actor groups in the early stage of a new technology and industry, however, is much less analyzed."

The contribution of this paper is to fill these two gaps in the literature by focusing on how alliances promote the legitimacy of organizations that develop, produce and sell a sustainable technology, and how alliances promote the legitimacy of the sustainable technology itself. In order to fill these gaps, the paper extends the framework by Dacin et al. (2007) on the legitimating roles of alliances to the context of sustainable technologies. On the basis of motives and sources of legitimacy, Dacin et al. (2007) identified different legitimacy types that can be achieved by alliances, such as market and social legitimacy. The motive of market legitimacy is to increase an organization's legitimacy in a geographical or product market and the source is the experience and reputable image of the alliance partner in the market. The motive of social legitimacy is to enhance an organization's legitimacy as a socially responsible actor and the source is the social image of the alliance partner (Dacin et al., 2007).

In the context of a sustainable technology, this paper shows that alliances aim to enhance the market and social legitimacy of organizations by using the technology of an alliance partner or the technology that is collaboratively developed in the alliance as a source of legitimacy, as opposed to using the experience or image of a partner as a source of market or social legitimacy. We refer to these types of legitimacy as organizations' technology-sourced market legitimacy and technology-sourced social legitimacy. In addition, the paper identifies a variety of sources (positive externalities, signaling, and institutional entrepreneurship) on which alliances rely to promote the legitimacy of the technology (Bergek et al., 2008; Lechner et al., 2006; Doblinger and Soppe, 2013). In order to achieve a better understanding of the alliances that promote technology-sourced market legitimacy, technology-sourced social legitimacy and technology legitimacy, the paper demonstrates how alliance attributes differ between alliances that promote the different forms of legitimacy. We establish differences between the alliances in terms of the organizational background of alliance partners, the number of alliance partners and the business functions of the alliance in the value chain (Oliver and Ebers, 1998; Kim et al., 2003).

To make these contributions to the literature on legitimacy, we have built a database on alliances using data from press releases, newspaper articles, company websites and industry journals. The database contains information on 105 alliances in the field of bioplastics over the period 1990-2013. The analysis of this data allows us to improve our understanding of the sources of legitimacy in the context of sustainable technologies, and provides industry participants with insights on how they can use alliances to stimulate their own and the technology's legitimacy. The following section discusses the literature on legitimacy and alliances. Section 3 presents the data collection methods. Section 4 discusses our results, and Section 5 offers a conclusion and discussion of the paper.

\section{Literature review}

Legitimation (or the creation of legitimacy) refers to the social justification of an actor or activity, such that the actor or activity is publicly validated or endorsed (Perrow, 1961; quoted in Dacin et al., 2007). Legitimacy is a generalized perception or assumption that the actions of an entity are desirable (Rao et al., 2008). It can be ascribed to different kinds of entities such as individuals, organizations, business models, industries and technologies (Aldrich and Fiol, 1994; quoted in Markard et al., 2016). In this paper, we study the creation of legitimacy of a technology and the legitimacy of organizations that research, develop, produce, market or promote the technology.

Organizations value a high degree of legitimacy, because their success depends on how others judge their appropriateness and the desirability of their technologies (Seo and Creed, 2002; Greenwood et al., 2011). Legitimate organizations have better access to markets and critical resources (Dacin et al., 2007), and legitimacy is central for novel and established technologies to mobilize resources necessary for growth and survival (Markard et al., 2016).

Since legitimacy is "created in a collective social process" (Markard et al., 2016: 331), and is transacted or exchanged between organizations (Pfeffer and Salancik, 2003), we focus on the role of inter-organizational alliances in creating legitimacy of organizations and technologies. Dacin et al. (2007: 172) have argued that "due to the transactional and social nature of alliances, it is especially important to examine legitimacy within an alliance context". The following sections discuss the role of alliances in creating legitimacy of organizations and technologies in more detail.

\subsection{Creating legitimacy of organizations: the role of alliances}

Alliances are voluntary collaborations between organizations that involve the exchange, sharing or co-development of products, technologies, and services to pursue a common set of goals or meet critical business needs (Gulati, 1998; Lin, 2012). It has been argued that alliances can enhance the legitimacy of organizations (Dacin et al., 2007). For instance, an alliance between a new business venture and an established entity may confer legitimacy on the former, and the mere existence of the alliance carries an endorsement of the alliance partners (Rao et al., 2008). Dacin et al. (2007) propose that five types of legitimacy needs of firms play an important role in alliance formation, as is shown in Table 1. An alliance may provide market, social or relational legitimacy for a focal firm, investment legitimacy for a firm's activities, and alliance legitimacy for the alliance in general. Firms can enter into an alliance with one or several of these five legitimacy goals in mind (Dacin et al., 2007).

First, Table 1 shows that a firm may enter into an alliance to enhance its rights or qualifications to operate in a particular market, and it may use the reputable image of the alliance partner as a source of market legitimacy. This need for market legitimacy can be driven by a lack of experience, reputation or performance of a firm. A firm may acquire market legitimacy by forming an alliance with a firm in a related but established industry, thus gaining immediate access to the legitimacy that the established firm already possesses (Rao et al., 2008). Second, a firm can be motivated to form an alliance to increase its image as a socially responsible firm, by partnering with organizations that have a good social image. Third, a firm may form an alliance to demonstrate it is a worthy partner. This search for relational legitimacy can be driven by a lack of history as a good alliance partner and a need for alliances in the future to enhance the firm's performance. The relationship with the partner is used as a source of relational legitimacy. Fourth, an alliance can serve to legitimate the business activities of participating firms in the eyes of corporate insiders. This need for investment legitimacy will be high when the business activity has not been adopted by the focal firm or by other organizations in the past. Finally, in some circumstances the legitimacy of alliances as a form of business transaction needs to be established. Alliance legitimacy can be important in fields that do not have a history of alliance use 
Table 1

Legitimating roles of alliances, adapted from Dacin et al. (2007).

\begin{tabular}{|c|c|c|c|c|c|}
\hline & Market legitimacy & Social legitimacy & Relational legitimacy & Investment legitimacy & Alliance legitimacy \\
\hline Definition & $\begin{array}{l}\text { Rights and } \\
\text { qualifications to } \\
\text { conduct business in a } \\
\text { particular market }\end{array}$ & $\begin{array}{l}\text { Conformity of the firm } \\
\text { to societal rules and } \\
\text { expectations }\end{array}$ & $\begin{array}{l}\text { Worthiness to be a } \\
\text { partner }\end{array}$ & $\begin{array}{l}\text { Worthiness of the } \\
\text { business activity }\end{array}$ & $\begin{array}{l}\text { Validity or } \\
\text { appropriateness of } \\
\text { strategic alliances }\end{array}$ \\
\hline Motive for entering alliance & $\begin{array}{l}\text { To increase one's } \\
\text { legitimacy in a } \\
\text { geographical or product } \\
\text { market }\end{array}$ & $\begin{array}{l}\text { To increase one's } \\
\text { legitimacy as a socially } \\
\text { responsible firm }\end{array}$ & $\begin{array}{l}\text { To increase one's } \\
\text { legitimacy as a good } \\
\text { partner }\end{array}$ & $\begin{array}{l}\text { To increase the } \\
\text { legitimacy of the } \\
\text { business activity }\end{array}$ & $\begin{array}{l}\text { To legitimate alliance } \\
\text { use }\end{array}$ \\
\hline Source of legitimacy & $\begin{array}{l}\text { Partner's legitimacy in } \\
\text { the market }\end{array}$ & Partner's social image & $\begin{array}{l}\text { Relationship with } \\
\text { partner }\end{array}$ & $\begin{array}{l}\text { Partner's support and } \\
\text { confidence in the } \\
\text { business activity }\end{array}$ & Isomorphism \\
\hline
\end{tabular}

while acceptance of the alliance form is important for achieving other types of legitimacy. Table 1 illustrates that we can distinguish between these five legitimacy types by analyzing the motive of firms for entering into an alliance and the source of the legitimacy.

This framework by Dacin et al. (2007) focuses on the role of alliances in creating legitimacy of organizations, but it underemphasizes two crucial aspects of legitimacy in the context of sustainable technologies. First, organizations do not solely rely on the reputation, experience or image of alliance partners to enhance their own legitimacy, but they also use the sustainable technology of a partner or one that is collaboratively developed in the alliance as a source of legitimacy (Section 2.2). Second, organizations may not only be motivated to enhance their own legitimacy, but also the legitimacy of the sustainable technology itself (Section 2.3). In other words, the study of legitimacy must pay attention to sustainable technologies as both a source and a motive of legitimacy in alliance formation.

\subsection{Creating legitimacy of organizations using technologies: the role of alliances}

In order to study technology as a source of legitimacy, we extend the framework by Dacin et al. (2007) to the context of sustainable technologies and focus on market and social legitimacy. This focus is justified when we take into account the well-known integrational perspective on sustainability, which defines sustainable development as the simultaneous pursuit of economic and social/ environmental dimensions (e.g. Lozano, 2008).

When we compare market legitimacy in the context of sustainable technologies to market legitimacy in the framework by Dacin et al. (2007), we expect that the motive of organizations is the same, but the source of legitimacy may be different. Organizations aim to increase their legitimacy in a geographical or product market (i.e. motive), but do not use the overall experience or reputation of the alliance partner as a source of market legitimacy. Instead, organizations relate their rights and qualifications to conduct business in a specific market to the technology of the partner or to the technology developed in the alliance. We refer to this type of legitimacy as an organization's technology-sourced market legitimacy.

In addition to market legitimacy, social legitimacy is relevant in the context of sustainable technologies. Organizations may enter the business of sustainable technologies to increase their legitimacy as a socially responsible organization, and use alliances to pursue this motive. For instance, firms that sell products and services to end users may wish to improve the sustainability of their supply chain, by including sustainable inputs in the production process or by increasing the sustainability of the products' packaging (Niesten and Lozano, 2015). They improve their social legitimacy by forming alliances with firms that possess the technologies to produce sustainable inputs and packaging. In this way, firms can relate their conformity to social rules and expectations to the sustainable technology of the partner or to the technology developed in the alliance. The adoption or development of sustainable innovations can signal that a firm is being responsible and is complying with social expectations. We refer to this type of legitimacy as an organization's technology-sourced social legitimacy. While the motive of this type of legitimacy is the same as in the framework by Dacin et al. (2007) (i.e. increase one's legitimacy as a socially responsible organization), the source of the social legitimacy is different: the source is not necessarily the partner's social image but the sustainable nature of the partner's or the alliance's technology.

\subsection{Creating legitimacy of technologies: the role of alliances}

Alliances do not only stimulate the legitimacy of organizations, but also the legitimacy of technologies. Innovation studies stress the importance of legitimation of new technologies and increasing the legitimacy of a new field to increase the chances of successful adoption of new technologies (e.g. Hekkert et al., 2007). When a technology is perceived to be desirable and appropriate by a broad spectrum of actors, its diffusion is facilitated. A technology that possesses a high degree of legitimacy is a technology that is well understood, compatible with established practices, socially accepted and perhaps even endorsed by regulation (Markard et al., 2016). Eisenhardt and Schoonhoven (1996) have argued that alliances can promote the legitimation of pioneering technologies by tying firms and their resources to the technology. While the motive for this type of legitimacy is apparent in the literature, there is less empirical evidence on the source of this legitimacy in the context of alliance formation. We propose three different ways in which alliances can enhance technology legitimacy. First, positive externalities may lead to the legitimacy of a technology. Positive externalities refer to private transactions that bring benefits to third parties that are not directly (or immediately) part of the transaction (Rangan et al., 2006). Bergek et al. (2008) have argued that the presence of positive externalities may increase legitimacy of a technology by attracting new entrants to an emerging technology field. As the market increases due to the new entrants, barriers to entry for yet more firms are lowered, and a larger market signals legitimacy. Rangan et al. (2006: 739) propose that "when the realization of economic opportunity...entails significant positive externalities (i.e. implies private actions with significant public benefits)...then private-public alliances are necessary for realizing the economic potential." In relation to this literature, we propose that positive externalities can be a source of technology legitimacy in the context of alliances. Alliances may enhance the possibilities to benefit from positive externalities and thereby stimulate technology legitimacy. For instance, a third party may use the outcomes of an $R \& D$ alliance to further develop or produce the new technology. 
Second, the literature on alliances has shown that relationships between firms can have important reputational or signaling effects (Gulati and Higgins, 2003; Deeds et al., 2004). Dacin et al. (2007: 170) have argued that "the signaling characteristics of alliances may serve as a source of legitimacy". For instance, new business ventures collaborate with reputational partners to overcome their liability of newness and gain legitimacy, by communicating the alliance to the outside world (Lechner et al., 2006). This signaling role of alliances can also be extended to promoting technology legitimacy, meaning that firms enter into alliances with reputable partners to stimulate the legitimacy of a technology.

Third, alliances may function as institutional entrepreneurs. In mature fields, organizations can use the field's standards and norms to obtain legitimacy (Aldrich and Fiol, 1994; Zimmerman and Zeitz, 2002). In emerging fields, however, technological standards are often unclear and innovations compete with existing technologies that are adapted to the institutional setting (Eisenhardt and Schoonhoven, 1996; Garud et al., 2002). Alliances can try to establish new institutions (e.g. standards, certificate systems, regulations, norms) that provide guidance with respect to evaluating the new technology, and that improve the legitimacy of the technology (Binz et al., 2016; Garud et al., 2002). Alliances act as institutional entrepreneurs when they envision new institutions and undertake actions to realize the new institutional setup (DiMaggio, 1988; Garud et al., 2002; Greenwood and Suddaby, 2006). Doblinger and Soppe (2013) have shown that partnerships between social movement organizations and incumbents in the energy sector initiate the institutional change necessary to legitimate renewable energy technologies. Smink et al. (2015) have demonstrated that collaborations between incumbents stimulate institutional change in the field of bio-methane. In this paper, we build on this literature, and analyze how alliances act as institutional entrepreneurs with the aim of stimulating technology legitimacy in the field of bio-plastics. Table 2 summarizes the motives and sources of the three types of legitimacy in the context of sustainable technologies.

\subsection{Attributes of alliances and legitimacy of organizations and technologies}

An extensive literature on alliances exists in the fields of strategic management, organizational economics and institutional theory (e.g. Jolink and Niesten, 2012; Niesten and Jolink, 2015). One stream within this literature focuses on identifying alliance attributes and their impact on firm and alliance performance (Jolink and Niesten, 2012). Some prominent examples of alliance attributes are the organizational background of alliance partners, the number of partners, and the business function of the alliance (e.g. Oliver and Ebers, 1998; Kim et al., 2003). Dacin et al. (2007) have argued that alliance attributes, and in particular the selection of an alliance partner, will be determined by the legitimacy needs that the partner can fulfill. What follows from this is that different legitimacy needs will lead firms to select a different type of alliance partner. We therefore expect that alliances that stimulate technology-sourced market legitimacy, technology-sourced social legitimacy and technology legitimacy will have different alliance attributes.

With respect to the organizational background of alliance partners, we may distinguish between private organizations (i.e. firms) and public organizations (Rangan et al., 2006). Inter-firm collaborations refer to alliances between private organizations, whereas inter-organizational alliances also consist of public organizations. Rangan et al. (2006) have argued that when positive externalities (i.e. the potential to create public benefits) exist, interorganizational alliances are necessary for realizing the economic potential. Since positive externalities are proposed to be a source of technology legitimacy, we may expect inter-organizational alliances to more often stimulate technology legitimacy as opposed to other forms of legitimacy. We also expect that inter-firm relations are more often associated with aiming for market legitimacy, because this type of legitimacy can be achieved by forming an alliance with a successful business partner. Dacin et al. (2007) argue that in order to achieve credibility in a market a firm will need to collaborate with a partner that has a successful business in that market: "A firm with a need for market legitimacy... will emphasize selection criteria that relate to a partner's abilities and competencies to do business in the intended geographical or product market" (Dacin et al., 2007: 180).

Bilateral alliances consist of two alliance partners, and multilateral alliances have three or more partners (Oliver and Ebers, 1998). In multilateral alliances, firms are associated with multiple partners and therefore have a higher visibility. Li (2013) has argued that this increased visibility of firms in multilateral alliances can help the legitimacy of a new technology of one of the partners, which otherwise may not be recognized or approved in intensely competitive markets. Hence, we expect that technology legitimacy as a motive is associated more often with multilateral alliances.

Different business functions in the value chain of alliances exist, such as research and development, manufacturing and marketing (Kim et al., 2003). Turcan (2013: 248-9) associated the first stages of the value chain with technology legitimacy and the latter stages with market legitimacy: "During the process of opportunity emergence, entrepreneurs are primarily concerned with technology legitimacy, which pertains to how to validate an innovation that has been created to meet a need or solve a problem...Entrepreneurs are then faced with the quest to better understand the target market, and how to get the product to that market...hence, the issue of market legitimacy arises." Therefore, we expect to find technology legitimacy motives more often in alliances in early stages of the value chain.

The study of alliance attributes will offer a better understanding of what type of alliances stimulate different forms of legitimacy. On the basis of existing literature, we expect that technology legitimacy is more often associated with inter-organizational, multilateral alliances in the early stages of the value chain, when compared to the two other forms of legitimacy.

\section{Methods}

\subsection{Research setting}

The global plastics industry has steadily grown since the 1950s, and demand for plastics is likely to continue to rise (PlasticsEurope, 2013). Plastics are produced mainly from petroleum and represent the largest field of application for crude oil (Siracusa et al., 2008; Shen, 2011). The first oil crisis in 1973 raised public concern over

Table 2

Legitimating roles of alliances in the context of sustainable technologies.

\begin{tabular}{|c|c|c|c|}
\hline & Technology-sourced market legitimacy & Technology-sourced social legitimacy & Technology legitimacy \\
\hline Motive for entering alliance & $\begin{array}{l}\text { To increase organization's legitimacy in } \\
\text { a geographical or product market }\end{array}$ & $\begin{array}{l}\text { To increase organization's legitimacy as } \\
\text { being socially responsible }\end{array}$ & To increase the legitimacy of the technology \\
\hline Source of legitimacy & $\begin{array}{l}\text { Technology of the partner; technology } \\
\text { developed in the alliance }\end{array}$ & $\begin{array}{l}\text { Sustainable technology of the partner; } \\
\text { sustainable technology developed in } \\
\text { the alliance }\end{array}$ & $\begin{array}{l}\text { Positive externalities; signaling; institutional } \\
\text { entrepreneurship }\end{array}$ \\
\hline
\end{tabular}


limited fossil resources (Siracusa et al., 2008). The prospect of feedstock supply insecurities was a first trigger for the plastics industry to start looking for alternative raw materials suited for plastics production. In the period 1980-1990 other environmental issues emerged, and attention was drawn to rapidly increasing amounts of waste and limited landfill capacities (Shen et al., 2009). Two crucial aspects of plastics (i.e. petro-based production and durability) are directly related to these environmental problems (Ren, 2003; Shen et al., 2009; Chadha, 2011).

Following these events, bio-based plastics gained attention as possible sustainable innovations. Bio-plastics are bio-degradable and/or made from bio-based raw materials (Álvarez-Chávez et al., 2012; Iles and Martin, 2013). They have the potential to reduce the dependency of plastics production on oil and to contribute to solving environmental issues. A first wave of bio-plastics was introduced to the market in the early 1990s. However, these plastics did not perform as advertised, and bio-plastics became associated with misleading environmental claims and sub-par performance (Iles and Martin, 2013). A second wave of bio-plastics emerged in the 2000s, due to technological developments and increased attention for climate change (Iles and Martin, 2013). Firms from many different industries, including the food, agricultural and chemical industry, have entered the field of bio-plastics.

\subsection{Case selection}

Within this field, we focus on bio-plastics that are produced for consumer markets and are thus consumed by end users. We also include inputs that are developed to produce these bio-plastics, such as succinic acid or 1,4-butanediol. We focus on these markets, because the issue of legitimacy is especially relevant in markets in which consumers are deciding on whether the technology is appropriate and desirable. The majority of these bio-plastics are used for durable consumer goods and packaging of consumer durable and nondurable goods. We exclude bio-polymers related to fibers, yarn, and textile, as these are related to different markets. Bio-plastics in medical applications have been excluded for the same reason. We also exclude so-called oxo-degradable plastics. These plastics have been marketed as bio-plastics in the past but are essentially petro-based plastics with additives that enable them to degrade under certain conditions into micro-plastics. However, these plastics have been criticized for not being truly biodegradable and/or bio-based.

\subsection{Data collection and analysis}

The data on alliances in the field of bio-plastics is collected from several sources. Following the research suggestion of Wassmer et al. (2014), our secondary data sources are European industry journals, newspaper articles, press releases, and corporate websites. Data is collected for the period 1990-2013. The starting point is in line with the first commercial wave of bio-plastics that emerged after petro-based plastics became dominant. We include a diverse set of alliances, such as joint ventures, contractual alliances, consortia, associations, and public-private partnerships. The alliance partners retain their own legally autonomous organizations, meaning that we do not consider mergers and acquisitions as part of alliances (Ménard, 2004; Jolink and Niesten, 2012).

It can be argued that many of the data sources, such as industry journals and press releases, present a biased interpretation of events and issues (Hoffman, 1999). However, this output directly influences perceptions of actors in the field. Consider for instance that an alliance is formed with various goals in mind, but in the press release the only motivation mentioned is obtaining market legitimacy. As this message influences interpretation in the field, this bias reflects the attention of the alliance partners (Hoffman, 1999) and is thus exactly the data we need to study legitimacy. In order to fully capture these effects, multiple news items on each alliance have been studied.

The data sources were scanned for alliances in the field of bioplastics. The main search terms used were varieties of bio-plastic, bio-polymer, bio-based plastic, sustainable plastic, and renewable plastic and were combined with terms such as collaborate, cooperate, partner, joint venture, and alliance. These search terms were used in LexisNexis, Bioplastics Magazine (the only independent trade magazine worldwide dedicated to bio-plastics) and the Green Chemicals blog (a leading blog documenting green developments in the chemical industry). For each alliance that is in line with our definitions of alliances and bio-plastics, we recorded the alliance year, names of alliance partners, number of partners, organizational background of partners, business function of the alliance, and types of legitimacy. Two researchers coded the variables used in this study. In a few instances the coding differed between the two researchers, which was resolved by discussing the details of the alliance and collecting more information about the alliance on companies' websites.

\subsubsection{Coding legitimacy}

Whereas previous research has measured legitimacy as a dummy variable on the basis of whether a firm entered into an alliance with an established firm (e.g. Rao et al., 2008), we aimed to offer a more elaborate codification of legitimacy in the context of alliances. The data on alliances were scanned for the motives of obtaining legitimacy (i.e. the type of legitimacy that partners want to increase) and the sources of legitimacy (i.e. how the alliance is expected to increase legitimacy). We coded the data using the categorization of Table 2. Firms aim for technology-sourced market legitimacy when they enter into alliances to increase their market legitimacy by using a technology of the alliance or alliance partner as the source of legitimacy. In the case of technology-sourced social legitimacy, firms enter into alliances to enhance their social legitimacy by using a sustainable technology of the alliance or alliance partner as the source of legitimacy. Alliances stimulate technology legitimacy when the motive is to increase the legitimacy of the technology and the source relates to positive externalities, signaling roles of alliances or institutional entrepreneurship activities of alliances.

\subsubsection{Coding alliance attributes}

We identified three attributes of alliances in the data, including the organizational background of the partners, the number of partners, and the business function of the alliance. With respect to the organizational background of partners, we coded alliances as inter-firm alliances when only private organizations (i.e. firms) are part of the alliance. Alliances that included public organizations, such as a state, (local) government, university, NGO, or a stateowned organization, were coded as inter-organizational alliances. Bilateral alliances are alliances with two alliance partners, and multilateral alliances involve three or more partners. We also coded the three business functions of the alliance, which include $R \& D$, manufacturing, and marketing (Kim et al., 2003):

- R\&D: alliance carries out research or develops a technology that is specific for the alliance

- Manufacturing: alliance starts with the establishment of production capacity

- Marketing: alliance starts after production phase, focused on bringing products to specific markets

During the coding process, we discovered that several alliances 
do not pursue any research or develop a new technology, nor do they manufacture or market a product. We refer to these alliances as alliances that are in the pre-competitive stage of business activities.

\section{Results: legitimacy in the field of bio-plastics}

This section presents the results on alliances that stimulate technology-sourced market legitimacy (Section 4.1), technologysourced social legitimacy (Section 4.2) and technology legitimacy (Section 4.3) in the field of bio-plastics. In Section 4.4, we discuss how alliances that stimulate the different types of legitimacy differ from other alliances in our dataset, in terms of the organizational background of alliance partners, the number of partners, and the business functions of the alliance in the value chain. Appendices $\mathrm{A}$ and $B$ offer a short description of the data sources and the organizations that are referred to in the results.

\subsection{Technology-sourced market legitimacy}

In 40 alliances in our dataset, the motive is to obtain market legitimacy by using technology as a source of legitimacy. We discuss the different ways in which these alliances pursue technology-sourced market legitimacy.

First, organizations aim to increase their legitimacy in a market by accessing the technology of their alliance partner. An example of this type of legitimacy is the alliance between Bayegan and Myriant, in which Bayegan accesses Myriant's technology. The CEO of Bayegan comments on the alliance: "Increasingly, our customers are seeking high-performing, renewable chemicals, like bio-succinic acid. Through our partnership with Myriant, Bayegan can reliably deliver an innovative, in-demand product that adds significant value for our customers" (Myriant, 2013). Another example is the alliance between packaging producer Oerlemans Plastics BV and FKuR (a company that has developed packaging based on PLA blends), through which Oerlemans can better serve a market by accessing the technology of FKuR. The press release on the alliance mentions the following: "Responding to the increase in the demand for biodegradable and compostable films and packaging Oerlemans Plastics is cooperating with FKuR in Germany in order to better serve the upcoming organic market" (Bioplastics Magazine, 2009a).

Second, an organization may aim to increase its market legitimacy by providing the technology of its alliance partner with access to markets or production capacity. In September 2012 Sulzer Chemtech entered into an alliance with NatureWorks: "This project has been a natural marriage of each company's assets, focused on a subset of NatureWorks' patented process technology to bring both new capacity and new products to the market" (NatureWorks, 2012a). By offering production capacity Sulzer could increase its legitimacy with this alliance: "Additional work was done in our test center with two primary benefits in focus - increased capacity and product extension. The project development provided an exciting professional and technical opportunity for us to show our capabilities for this type of application" (NatureWorks, 2012a).

Third, alliance partners may also increase their legitimacy by collaboratively developing or selling a technology to access a market. For instance, Altuglas International and NatureWorks have signed a global co-marketing agreement. "Through the collaboration, Altuglas International and NatureWorks will pool resources to accelerate the introduction of these new high performance biopolymer alloys into the market. By combining our respective reputations and strengths in biopolymers and acrylics, NatureWorks and Altuglas International will co-market clear materials that offer a complete package of innovative product performance" (NatureWorks, 2012b).

\subsection{Technology-sourced social legitimacy}

In 41 alliances in our dataset organizations attempt to obtain social legitimacy based on a sustainable technology. In several alliances, organizations pursue social legitimacy by collaboratively developing a sustainable technology or by accessing the sustainable technology of the alliance partner. BASF and Purac have collaboratively developed a technology that can serve as an input in the production of bio-plastics. The research director of BASF comments on the alliance with Purac and emphasizes BASF's sustainability goals: "Our strategy clearly focuses on innovations for a sustainable future. The development of a succinic acid production process based on fermentation in cooperation with Purac is a good example of this strategy being put into practice" (BASF, 2012). In the alliance between H.J. Heinz and The Coca-Cola Company, Heinz obtained access to the PlantBottle technology developed by Coca-Cola for use in Heinz's products. Heinz argues that "this partnership is a great example of how businesses are working together to advance smart technologies that make a difference to our consumers and the planet we all share" (Bioplastics Magazine, 2011). Heinz links the use of Coca-Cola's technology to making a difference for the planet, thereby using the sustainable technology as a source of social legitimacy. A similar line of reasoning is found in other alliances. De Ster, a Belgian firm producing plastic cutlery for the aviation industry, argues that they entered into an alliance with Biotec based on "a desire to work on our social responsibility" (NRC Handelsblad, 1996). De Ster refers to the compostable technology of Biotec as a means to be socially responsible, and it reinforces this by stating that the technology is currently more expensive than conventional plastics.

Organizations may also obtain social legitimacy by increasing the number of customers that can access their sustainable technology or by offering production capacity and a customer base to the sustainable technology of an alliance partner. The alliance between BASF and Purac illustrates this: "Our cooperation with Purac to produce biobased succinic acid is a perfect example of how we enable our customers in many industries to develop sustainable solutions" (BASF, 2012). Another example is the alliance between The Coca Cola Company and Avantium, which is a company that has developed a technology to produce PEF (polyethylene-furanoate) bottles. Coca Cola offers a large production capacity and a large number of customers to the sustainable technology of Avantium: "PEF is $100 \%$ biobased and when commercialized will be fully recyclable. We are very excited about the co-development phase we are entering with The Coca-Cola Company to continue the development of PEF and make this new material ready for mass production and recycling. Their leadership and experience in commercializing biobased materials make them a great partner to work with as we commercialize this exciting new material" (Avantium, 2011).

\subsection{Technology legitimacy}

Establishing technology legitimacy plays a prominent role in alliance formation in the bio-plastics field. In total, we identified 63 alliances with a technology legitimacy motive. We will discuss the different sources on which these alliances rely to enhance the desirability or appropriateness of a sustainable technology.

The majority of these 63 alliances stimulate technology legitimacy by developing or producing multiple applications of the technology, thereby allowing for an increased adoption of the technology in entire supply chains or across different sectors. The press releases refer to alliances that allow "for bio-based product solutions in applications that were previously difficult to address" (NatureWorks, 2012c) and that "elaborate on the application of bioplastics for the entire life cycle" (Bioplastics Magazine, 2009b). A 
research analyst of Frost \& Sullivan commented on the alliance between Purac and Sulzer Chemtech, and mentioned that "The companies are lauded for their efforts at realizing a novel, economical polymerization process and their commitment toward commercializing this technology for varied high-performance applications" (Frost and Sullivan, 2008). This new process will "enable a more efficient production of different PLA products and will reduce the process and product development time. In addition, the new process requires limited investment and will, therefore, be more affordable, significantly lowering the entry barrier for PLA production" (Frost and Sullivan, 2008). These examples show that creating legitimacy for the new technology does not only benefit the alliance partners, but also firms that wish to start producing PLA. The press releases refer to broad technology categories (for instance all polylactic acid (PLA) plastics, and not one specific brand), implying that other firms using comparable technologies can benefit from the efforts of the focal alliance. This is therefore a first example of a positive externality as a source of technology legitimacy.

Several other alliances promote technology legitimacy by expanding the markets in which the technology can be sold, thereby expanding the number of firms that can produce and sell the technology. The purpose of a collaboration between Avantium and Alpla is "to create a market pull for PEF, which will de-risk the value chain for other partners like feedstock suppliers, chemical companies, resin producers and recyclers, which are essential to put a new polyester on the market" (Bioplastics Magazine, 2013). The CEO of Metabolix commented on the alliance between his company and ADM: "This agreement is a major advance toward our goal of making an array of renewable, eco-friendly alternatives to traditional petrochemical plastics widely available to the global marketplace" (Metabolix, 2004). These examples illustrate that the alliance partners do not (only) aim for legitimacy of their own firm but for legitimacy of the technology by creating opportunities that also benefit other firms (e.g. lower entry barriers, de-risking the value chain), again illustrating that positive externalities are a source of technology legitimacy.

A few press releases refer to the signaling role of alliances in which famous alliance partners promote the legitimacy of a new technology. Gevo and The Coca-Cola Company entered into an alliance to develop the PlantBottle, which is packaging made from plant-based materials. The CEO of Gevo mentioned that "New technologies need champions. The Coca-Cola Company is in a unique position to drive and influence change in the global packaging supply chain with this development. You cannot ask for a better champion than one of the world's most respected and admired consumer brands" (Gevo, 2011).

In addition to this signaling role, alliances act as institutional entrepreneurs by lobbying for new legislation, regulation, standards and certificates for the technology. For instance, European Bioplastics, which is an association representing the bio-plastics industry, "closely monitors, discusses and contributes to relevant EU legislation concerning the European bioplastics industry" (European Bioplastics, 2015). Another example is the Belgian Biopackaging association, which: "obtained with targeted lobbying work some important modifications to the local waste legislation and supported the creation of the first law in Europe that defines the terms compostable, home compostable and degradable in the soil" (nova-Institute, 2015). The promotion of technologies towards external actors and the creation of supporting institutions are also observed in several brand-owner alliances. The most prominent ones are the Plant PET Technology Collaborative (PTC) (partners: Coca-Cola, Ford, Heinz, Nike, Procter \& Gamble) and the Bioplastic Feedstock Alliance (partners: Coca-Cola, Danone, Ford, Heinz, Nestle, Nike, Procter \& Gamble, Unilever, WWF). The first builds on Coca-Cola's PlantBottle technology. This alliance "seeks to drive the development of common methodologies and standards for the use of plant-based plastic including life cycle analysis and universal terminology. The brands will then promote these standards with the expectation that they will be endorsed and used worldwide by both PTC and non-PTC members" (PlasticsToday, 2012). In other words, this alliance tries to legitimate technologies by establishing institutions. These institutions may influence how actors outside the alliance evaluate the desirability and appropriateness of the technologies. In these alliances institutional entrepreneurship is thus used as a source of technology legitimacy.

Finally, alliances also display institutional entrepreneurship by promoting discussions between multiple stakeholders on the technology and by spreading knowledge on how the technology can be used. Two examples can be given of alliances with the explicit aim to create awareness of the technology. A first example is the Bioplastic Feedstock Alliance, which "was formed by some of the world's leading consumer brand companies as a precompetitive, multi-stakeholder forum focused on increasing awareness around the environmental and social performance of potential feedstock sources for bio-based plastics" (Bioplastic Feedstock Alliance, 2015). A second example is the Dutch Polymer Institute, which "provides a unique platform for generating awareness of new technology, in which participating industrial companies, competitors in the market place, communicate on a pre-competitive basis to trigger innovation" (Dutch Polymer Institute, 2015). Creating awareness of these new technological visions is an act of institutional entrepreneurship and can help increase the desirability and appropriateness of technologies.

\subsection{Attributes of alliances that stimulate legitimacy}

The previous section has shown how alliances promote various forms of legitimacy in the context of a sustainable technology. In this section, we aim to improve our understanding of the attributes of these alliances. We analyze how the alliances that promote different forms of legitimacy differ from each other, in terms of the partners' organizational background, the number of partners and the business function of the alliance.

Table 3 illustrates that alliances aimed at technology-sourced market legitimacy and technology-sourced social legitimacy are mainly inter-firm alliances (i.e. alliances between private organizations) and bilateral alliances (alliances between two firms). These alliances often focus on business functions that are characteristic of later stages of the value chain, such as manufacturing and marketing. These findings are in line with our theoretical expectations. We have compared these two groups of alliances to the remaining set of alliances in our dataset and find that the two groups differ significantly from the other alliances. An analysis of variance shows that there are significant differences (at the $1 \%$ level for each of the three alliance attributes) between alliances that stimulate technology-sourced market legitimacy $(n=40)$ and the remaining alliances $(n=65)$. An analysis of variance also shows that there are significant differences between alliances that stimulate technology-sourced social legitimacy $(n=41)$ and the other alliances $(n=64)$ at the $1 \%$ level for organizational background and number of partners, and at the $5 \%$ level for the business function. This means that we can identify alliances that promote technology-sourced market or social legitimacy as separate groups of alliances that differ from other alliances.

Alliances that stimulate technology legitimacy differ in certain respects from alliances that do not stimulate legitimacy of a technology in the field of bio-plastics (see Table 4). They are more often multilateral and inter-organizational alliances, meaning that the number of alliance partners is higher and the partners include governments (at state or local level), universities and research institutes, and NGOs. They often take the form of associations, consortia, or public-private partnerships. This is in line with the expectations 
Table 3

Alliances that stimulate technology-sourced market and social legitimacy.

\begin{tabular}{|c|c|c|}
\hline & Technology-Sourced Market Legitimacy $(n=40)$ & NO Technology-Sourced Market Legitimacy $(n=65)$ \\
\hline \multirow[t]{2}{*}{ Organizational background } & Inter-firm alliances: $95 \%$ & Inter-firm alliances: $66 \%$ \\
\hline & Inter-organizational alliances: $5 \%$ & Inter-organizational alliances: $34 \%$ \\
\hline \multirow[t]{2}{*}{ Number of partners } & Bilateral: $90 \%$ & Bilateral: $65 \%$ \\
\hline & Multilateral: $10 \%$ & Multilateral: $35 \%$ \\
\hline \multirow[t]{5}{*}{ Business function } & Pre-competition: $0 \%$ & Pre-competition: $12.3 \%$ \\
\hline & R\&D: $30 \%$ & R\&D: $49.2 \%$ \\
\hline & Manufacturing: $37.5 \%$ & Manufacturing: $23.1 \%$ \\
\hline & Marketing: $32.5 \%$ & Marketing: $15.4 \%$ \\
\hline & Technology-Sourced Social Legitimacy $(n=41)$ & NO Technology-Sourced Social Legitimacy $(\mathrm{n}=64)$ \\
\hline \multirow[t]{2}{*}{ Organizational background } & Inter-firm alliances: $95 \%$ & Inter-firm alliances: $66 \%$ \\
\hline & Inter-organizational alliances: $5 \%$ & Inter-organizational alliances: $34 \%$ \\
\hline \multirow[t]{2}{*}{ Number of partners } & Bilateral: $88 \%$ & Bilateral: $66 \%$ \\
\hline & Multilateral: $12 \%$ & Multilateral: $34 \%$ \\
\hline \multirow[t]{4}{*}{ Business function } & Pre-competition: $0 \%$ & Pre-competition: $12.5 \%$ \\
\hline & R\&D: $34.1 \%$ & R\&D: $46.9 \%$ \\
\hline & Manufacturing: $41.5 \%$ & Manufacturing: $20.3 \%$ \\
\hline & Marketing: $24.4 \%$ & Marketing: $20.3 \%$ \\
\hline
\end{tabular}

Table 4

Alliances that stimulate technology legitimacy.

\begin{tabular}{|c|c|c|}
\hline & Technology Legitimacy $(n=63)$ & No Technology Legitimacy $(n=42)$ \\
\hline \multirow[t]{2}{*}{ Organizational background } & Inter-firm alliances: $75 \%$ & Inter-firm alliances: $81 \%$ \\
\hline & Inter-organizational alliances: $25 \%$ & Inter-organizational alliances: $19 \%$ \\
\hline \multirow[t]{2}{*}{ Number of partners } & Bilateral: $68 \%$ & Bilateral: $83 \%$ \\
\hline & Multilateral: $32 \%$ & Multilateral: $17 \%$ \\
\hline \multirow[t]{3}{*}{ Business function } & Pre-competition: $12.7 \%$ & Pre-competition: $0 \%$ \\
\hline & $\mathrm{R} \& \mathrm{D}: 41.3 \%$ & R\&D: $42.9 \%$ \\
\hline & Manufacturing: $23.8 \%$ & Manufacturing: $35.7 \%$ \\
\hline
\end{tabular}

expressed in the theoretical section. The alliances that stimulate technology legitimacy also differ from other alliances, because they are formed in a pre-competitive stage, meaning that they do not only pursue R\&D, manufacturing or marketing. In this pre-competitive stage, the alliances are concerned with lobbying for new legislation, regulation, standards, and certification for the new technology. They also aim to increase awareness and inform consumers of the benefits of the new technology. An analysis of variance shows that there are significant differences between the two groups of alliances (those that stimulate technology legitimacy and those that do not) at the $10 \%$ level for number of partners and business function.

\section{Conclusion and discussion}

This paper focused on the role of alliances in creating legitimacy of organizations and their sustainable technologies. On the basis of an analysis of 105 alliances in the field of bio-plastics over the period 1990-2013, we identified a variety of sources on which alliances rely to promote three types of legitimacy.

In technology-sourced market legitimacy, alliances provide organizations with access to a technology and thereby enhance the legitimacy of these organizations in the market in which the technology is sold. In technology-sourced social legitimacy, alliances provide organizations with access to a sustainable technology and thereby improve the social image of the organizations. These two types of legitimacy differ from other legitimacy forms, because the source of legitimacy is the technology and not a partner's reputation or experience. Alliances that promote these types of legitimacy are often bilateral and inter-firm alliances that operate in later stages of the value chain, such as manufacturing and marketing.

A third form of legitimacy is technology legitimacy, with which alliances enhance the legitimacy of the (sustainable) technology itself. Our results show that alliances promote the desirability and appropriateness of a technology by relying on positive externalities, by exercising their signaling role, and by acting as institutional entrepreneurs. Alliances that stimulate technology legitimacy differ from other alliances, because they are more often multilateral alliances and operate in the pre-competitive stage of the value chain in which they focus on promoting standards, certificates, labels, and legislation for the technology.

The main contribution of this paper lies in identifying different sources of legitimacy in the context of sustainable technologies, and how alliances rely on these sources to promote the different forms of legitimacy for the alliance partners and for the sustainable technology they develop, produce or sell.

Future research could expand the study of legitimacy in relation to sustainable technologies and alliances by focusing on the analysis of investment, alliance and relational legitimacy. Previous studies have identified these as important types of legitimacy to be achieved by firms in collaboration with others. Our emphasis on market and social legitimacy may be due to our use of secondary data sources, and firms' preference for communicating about their reputation in the market and social image. Interviews with collaborating firms may enhance our understanding of the other types of legitimacy. Future research could also focus on output and performance implications. In particular, the research aim could be to determine to what extent the legitimacy has been achieved, what the implications for alliance performance are (e.g. financial or innovative performance), and what the consequences of increasing levels of legitimacy are for technology adoption rates.

\section{Acknowledgements}

The authors would like to thank prof. dr. Albert Jolink for providing valuable feedback on different versions of this paper, and dr. Roberto Antonietti for his valuable comments on an earlier version of this paper at the Governance of a Complex World Conference in July 2015. 
Appendix A. Data sources of quotes mentioned in Section 4.

\begin{tabular}{|c|c|c|}
\hline Reference & Title & Data source \\
\hline Avantium, 2011 & $\begin{array}{l}\text { Avantium and the Coca-Cola company sign partnership } \\
\text { agreement to develop next generation } 100 \% \text { plant based } \\
\text { plastic: PEF. }\end{array}$ & $\begin{array}{l}\text { avantium.com/news/2011-2/Avantium-and-The-Coca-Cola-Company- } \\
\text { sign-partnership-agreement-to-develop-next-generation-100-plant- } \\
\text { based-plastic-PEF.html }\end{array}$ \\
\hline BASF, 2012 & $\begin{array}{l}\text { BASF and CSM establish } 50-50 \text { joint venture for biobased } \\
\text { succinic acid. }\end{array}$ & $\begin{array}{l}\text { www.basf.com/documents/corp/en/news-and-media/news-releases/ } \\
\text { 2012/10/P444_BASF_Purac_2012_Oct4_e.pdf }\end{array}$ \\
\hline Bioplastic Feedstock Alliance, 2015 & Bioplastic Feedstock Alliance, 2015. Who we are. & www.bioplasticfeedstockalliance.org/who-we-are/ \\
\hline Bioplastics Magazine, 2009a & Bioplastic films from the Netherlands. & www.bioplasticsmagazine.com \\
\hline Bioplastics Magazine, 2009b & Biodegradable bags project in Thailand. & www.bioplasticsmagazine.com \\
\hline Bioplastics Magazine, 2011 & Ketchup in biobased PET. & www.bioplasticsmagazine.com \\
\hline Bioplastics Magazine, 2013 & New partner joins PEF bottle development. & www.bioplasticsmagazine.com \\
\hline Dutch Polymer Institute, 2015 & Dutch Polymer Institute, 2015 . Key facts. & www.polymers.nl/About/Keyfacts \\
\hline European Bioplastics, 2015 & European Bioplastics, 2015. Activities. & en.european-bioplastics.org/about-us/activities/ \\
\hline Frost and Sullivan, 2008 & $\begin{array}{l}\text { PURAC, Sulzer Chemtech and Synbra Technology jointly } \\
\text { awarded Frost \& Sullivan polylactic production technology } \\
\text { innovation of the year award. }\end{array}$ & www.frost.com/prod/servlet/press-release.pag?docid=177397034 \\
\hline Gevo, 2011 & $\begin{array}{l}\text { The Coca-Cola Company and Gevo Partner to Develop and } \\
\text { Commercialize } 100 \% \text { Renewable Plastic Bottles. }\end{array}$ & $\begin{array}{l}\text { ir.gevo.com/phoenix.zhtml?c=238618\&p=irol- } \\
\text { newsArticle\&ID }=1640177\end{array}$ \\
\hline Metabolix, 2004 & $\begin{array}{l}\text { Metabolix and ADM Enter Strategic Alliance to } \\
\text { Commercialize PHA Natural Polymers. }\end{array}$ & ir.metabolix.com/releasedetail.cfm?releaseid = 211091 \\
\hline Myriant, 2013 & $\begin{array}{l}\text { Myriant and Bayegan Group Partner to Commercialize } \\
\text { Renewable Chemicals. }\end{array}$ & $\begin{array}{l}\text { www.myriant.com/media/press-releases/myriant-and-bayegan-group- } \\
\text { partner-to-commercialize-renewable-chemicals.cfm }\end{array}$ \\
\hline NatureWorks, 2012a & $\begin{array}{l}\text { NatureWorks broadens Ingeo product portfolio with Sulzer } \\
\text { proprietary production equipment. }\end{array}$ & $\begin{array}{l}\text { www.natureworksllc.com/News-and-Events/Press-Releases/2012/09- } \\
\text { 05-12-Sulzer-equipment-for-increased-Ingeo-production }\end{array}$ \\
\hline NatureWorks, 2012b & $\begin{array}{l}\text { NatureWorks, } 2012 \mathrm{~b} \text {. Altuglas International and } \\
\text { NatureWorks launch worldwide marketing collaboration } \\
\text { for new high performance alloys incorporating Ingeo } \\
\text { biopolymers. }\end{array}$ & $\begin{array}{l}\text { www.natureworksllc.com/News-and-Events/Press-Releases/2012/12- } \\
\text { 11-12-Arkema-NatureWorks-collaborate-on-high-performance-alloys- } \\
\text { with-Ingeo-biopolymer }\end{array}$ \\
\hline NatureWorks, 2012c & $\begin{array}{l}\text { NatureWorks and BioAmber form joint venture to } \\
\text { commercialize new bio-based polymers. }\end{array}$ & $\begin{array}{l}\text { www.natureworksllc.com/News-and-Events/Press-Releases/2012/02- } \\
\text { 16-12-NatureWorks-BioAmber-Joint-Venture-AmberWorks }\end{array}$ \\
\hline Nova-Institute, 2015 & Belgian Biopackaging VZW/ASBL. & www.bio-based.eu/iBIB/pdf/8.pdf \\
\hline NRC Handelsblad, 1996. & Disney composteert voedselafval. & NRC Handelsblad, 1996 \\
\hline PlasticsToday, 2012. & Five major U.S. brands collaborating on plant-based PET. & $\begin{array}{l}\text { www.plasticstoday.com/articles/Five-major-US-brands-collaborating- } \\
\text { on-plant-based-PET-0605201202 }\end{array}$ \\
\hline
\end{tabular}

Appendix B. Description of organizations mentioned in

Section 4.

\begin{tabular}{|c|c|c|}
\hline Name of organization & Major industry (based on SIC code) & Short description of organization \\
\hline ADM & Food products & $\begin{array}{l}\text { One of the world's largest agricultural processors and food ingredient providers; it also produces } \\
\text { biofuels. }\end{array}$ \\
\hline Alpla & Paper & Leading company in packaging. Sells plastic bottles, caps, and preforms. \\
\hline Altuglas International & Chemicals & $\begin{array}{l}\text { Leading company in polymethyl methacrylate technology. Sells Plexiglas products (a sturdy transparent } \\
\text { plastic). }\end{array}$ \\
\hline Avantium & Research and development & $\begin{array}{l}\text { Technology company specialized in the area of advanced catalytic research. Developed YXY technology } \\
\text { to convert plant based materials into bioplastics. }\end{array}$ \\
\hline BASF & Chemicals & $\begin{array}{l}\text { Largest chemical producer worldwide. Operates in different markets; has named its segments } \\
\text { chemicals, plastics, performance products, functional solutions, agricultural solutions, and oil \& gas. }\end{array}$ \\
\hline Bayegan & - & $\begin{array}{l}\text { International distributer and trader of petrochemicals, chemicals, steel products, and other } \\
\text { commodities. }\end{array}$ \\
\hline Biotec & - & $\begin{array}{l}\text { Develops and produces sustainable bioplastics made from plant-based resources. Sells customized } \\
\text { thermoplastic materials under the brand name BIOPLAST. }\end{array}$ \\
\hline The Coca-Cola Company & Food products & $\begin{array}{l}\text { Multinational beverage corporation. Manufacturer, retailer and marketer of beverage concentrates and } \\
\text { syrups. Developed PlantBottle, bottle partially made from plants. }\end{array}$ \\
\hline De Ster & Plastics products & $\begin{array}{l}\text { Supplies aviation and rail industry with packaging for beverages and hot meals. Also sells cutlery and } \\
\text { trays. }\end{array}$ \\
\hline FKuR Kunststoff & Rubber and plastics products & $\begin{array}{l}\text { Leading producer of customized bioplastics. Sells a range of biobased and compostable resins under } \\
\text { different brand names (such as Bio-Flex). }\end{array}$ \\
\hline Gevo & Chemicals & $\begin{array}{l}\text { Renewable chemicals and biofuels company. Developed bio-based alternatives to petroleum-based } \\
\text { products using synthetic biology and chemistry. }\end{array}$ \\
\hline
\end{tabular}


(continued)

\begin{tabular}{|c|c|c|}
\hline Name of organization & Major industry (based on SIC code) & Short description of organization \\
\hline H.J.Heinz & Food products & Multinational food processing company. Mostly know for ketchup brand of the same name. \\
\hline Metabolix & Plastics products & $\begin{array}{l}\text { Advanced biomaterials company. Sells sustainable solutions to plastics industry, including PHA } \\
\text { biopolymers and biobased chemicals. }\end{array}$ \\
\hline Myriant & Chemicals & Produces bio-based chemicals. Sells different products, but most expertise in bio-succinic acid. \\
\hline NatureWorks & Chemicals & $\begin{array}{l}\text { Started as Cargill research project looking for innovative uses of carbohydrates of plants as feedstock for } \\
\text { plastics. One of the largest players in bioplastics. Sells bioplastics under Ingeo brand name. }\end{array}$ \\
\hline Oerlemans Plastics BV & Rubber and plastics products & Producer of plastics and packaging. Sells films and packaging to horticulture, agriculture and retail. \\
\hline Purac & Chemicals & $\begin{array}{l}\text { Currently operates under new name Corbion. Global market leader in lactic acid. Sells bioplastics in } \\
\text { markets: packaging \& disposables, consumer goods, consumer electronics, automotive. }\end{array}$ \\
\hline Sulzer Chemtech & Industrial and commercial machinery & $\begin{array}{l}\text { Leading player in fields of process technology and separating towers. Sells pumps and rotating } \\
\text { equipment in industries such as chemical processing, oil and gas, power generation, pulp and paper. }\end{array}$ \\
\hline
\end{tabular}

\section{References}

Aldrich, H., Fiol, C., 1994. Fools rush in the institutional context of industry creation. Acad. Manag. Rev. 19, 645-670.

Álvarez-Chávez, C.R., Edwards, S., Moure-Eraso, R., Geiser, K., 2012. Sustainability of bio-based plastics: general comparative analysis and recommendations for improvement. J. Clean. Prod. 23, 47-56.

Bergek, A., Jacobsson, S., Carlsson, B., Lindmark, S., Rickne, A., 2008. Analyzing the functional dynamics of technological innovation systems: a scheme of analysis. Res. Policy 37, 407-429.

Binz, C., Harris-Lovett, S., Kiparsky, M., Sedlak, D., Truffer, B., 2016. The thorny road to technology legitimation - Institutional work for potable water reuse in California. Technol. Forecast. Soc. Change 103, 249-263.

Chadha, A., 2011. From carbon to carbohydrates: corporate strategies for biopolymer technology development. J. Commer. Biotechnol. 16, 159-167.

Dacin, M., Oliver, C., Roy, J., 2007. The legitimacy of strategic alliances: an institutional perspective. Strateg. Manag. J. 28, 169-187.

Deeds, D., Mang, P., Frandsen, M., 2004. The influence of firms' and industries' legitimacy on the flow of capital into high-technology ventures. Strateg. Organ. 2, 9-34.

DiMaggio, P., 1988. Interest and agency in institutional theory. In: Zucker, L. (Ed.), Institutional Patterns and Organizations. Ballinger, Cambridge, pp. 3-22.

Doblinger, C., Soppe, B., 2013. Change-actors in the U.S. electric energy system: the role of environmental groups in utility adoption and diffusion of wind power Energy Policy 61, 274-284.

Eisenhardt, K., Schoonhoven, C., 1996. Resource-based view of strategic alliance formation: strategic and social effects in entrepreneurial firms. Organ. Sci. 7, 136-150.

Garud, R., Jain, S., Kumaraswamy, A., 2002. Institutional entrepreneurship in the sponsorship of common standards: the case of Sun Microsystems and Java. Acad. Manag. J. 45, 196-214.

Greenwood, R., Suddaby, R., 2006. Institutional entrepreneurship in mature fields: the big five accounting firms. Acad. Manag. J. 49, 27-48.

Greenwood, R., Raynard, M., Kodeih, F., Micelotta, E., Lounsbury, M., 2011. Institutional complexity and organizational responses. Acad. Manag. Ann. 5, 317-371.

Gulati, R., 1998. Alliances and networks. Strateg. Manag. J. 19, 293-317.

Gulati, R., Higgins, M., 2003. Which ties matter when? the contingent effects of interorganizational partnerships on IPO success. Strateg. Manag. J. 24, 127-144.

Hekkert, M., Suurs, R., Negro, S., Smits, R., Kuhlmann, S., 2007. Functions of innovation systems: a new approach for analyzing technological change. Technol. Forecast. Soc. Change 74, 413-432.

Hoffman, A.J., 1999. Institutional evolution and change: environmentalism and the U.S. chemical industry. Acad. Manag. J. 42, 351-371.

Iles, A., Martin, A.N., 2013. Expanding bioplastics production: sustainable business innovation in the chemical industry. J. Clean. Prod. 45, 38-49.

Jolink, A., Niesten, E., 2012. Recent qualitative advances on hybrid organizations: taking stock, looking ahead. Scand. J. Manag. 28, 1149-1161.

Kim, K., Park, J.-H., Prescott, J.E., 2003. The global integration of business functions: a study of multinational businesses in integrated global industries. J. Int. Bus. Stud. 34, 327-344.

Lechner, C., Dowling, M., Welpe, I., 2006. Firm networks and firm development: the role of the relational mix. J. Bus. Ventur. 21, 514-540.
Li, D., 2013. Multilateral R\&D alliances by new ventures. J. Bus. Ventur. 21, 241-260.

Lin, H., 2012. Strategic alliances for environmental improvements. Bus. Soc. 51, $335-348$.

Lozano, R., 2008. Envisioning sustainability three-dimensionally. J. Clean. Prod. 16, $1838-1846$.

Markard, J., Wirth, S., Truffer, B., 2016. Institutional dynamics and technology legitimacy - a framework and a case study on biogas technology. Res. Policy 45 $330-344$.

Ménard, C., 2004. The economics of hybrid organizations. J. Inst. Theor. Econ. 160, $345-376$.

Niesten, E., Jolink, A., 2015. The impact of alliance management capabilities on alliance attributes and performance: a literature review. Int. J. Manag. Rev. 17, 69-100.

Niesten, E., Lozano, R., 2015. Making, buying and collaborating for more sustainable production and consumption. J. Clean. Prod. 100, 1-3.

Oliver, A., Ebers, M., 1998. Networking network studies: an analysis of conceptua configurations in the study of inter-organizational relationships. Organ. Stud. $19,549-583$.

Perrow, C., 1961. Organizational prestige. Am. J. Sociol. 66, 335-341.

Pfeffer, J., Salancik, G., 2003. The external control of organizations: a resource dependence perspective. Stanford University Press, Stanford.

PlasticsEurope, 2013. Plastics - the Facts 2013. PlasticsEurope, Brussels.

Rangan, S., Samii, R., Van Wassenhove, L., 2006. Constructive partnerships: when alliances between private firms and public actors can enable creative strategies. Acad. Manag. Rev. 31, 738-751.

Rao, R., Chandy, R., Prabhu, J., 2008. The fruits of legitimacy: why some new ventures gain more from innovation than others. J. Mark. 72, 58-75.

Ren, X., 2003. Biodegradable plastics: a solution or a challenge? J. Clean. Prod. 11, $27-40$.

Seo, M.G., Creed, W., 2002. Institutional contradictions, praxis, and institutional change: a dialectical perspective. Acad. Manag. Rev. 27, 222-247.

Shen, L., 2011. Bio-based and Recycled Polymers for Cleaner Production - an Assessment of Plastics and Fibres. Ph.D. thesis. Copernicus Institute of Sustainable Development, Utrecht University.

Shen, L., Haufe, J., Patel, K., 2009. Product overview and market projection of emerging bio-based plastics PRO-BIP 2009. Rep. Eur. Polysaccharide Netw. Excell. (EPNOE) Eur. Bioplastics 243.

Siracusa, V., Rocculi, P., Romani, S., Dalla Rosa, M., 2008. Biodegradable polymers for food packaging: a review. Trends Food Sci. Technol. 19, 634-643.

Smink, M., Koch, J., Niesten, E., Negro, S., Hekkert, M., 2015. Institutional entrepreneurship in the emerging renewable energy field: incumbents versus new entrants, pp. 1-48. ISU Work. Pap. (15-01).

Thornton, P.H., Ocasio, W., 2008. Institutional logics. In: Greenwoord, R., Oliver, C., Suddaby, R., Sahlin-Andersson, K. (Eds.), The Sage Handbook of Organizational Institutionalism. Sage, London, pp. 99-129.

Turcan, R., 2013. International new venture legitimation: an exploratory study. Adm. Sci. 3, 237-265.

Wassmer, U., Paquin, R., Sharma, S., 2014. The engagement of firms in environmental collaborations: existing contributions and future directions. Bus. Soc. 53 754-786.

Zimmerman, M., Zeitz, G., 2002. Beyond survival: achieving new venture growth by building legitimacy. Acad. Manag. Rev. 27, 414-431. 